\title{
Odtworzyć świat (z) traumy O postmemorialnej prozie Görana Rosenberga Krótki przystanek w drodze z Auschwitz
}

\author{
Recreating a Universe of Trauma \\ On (Post)memorial A Brief Stop on the Road from Auschwitz \\ by Göran Rosenberg
}

\begin{abstract}
This article considers literary features that are characteristic of the (post)memorial prose written by members of the so-called "second generation" after Shoah: in other words, children of Holocaust Survivors, who grew up within spaces delineated by family memories that were strongly tabooed. Based on the example of the autobiographical text A Brief Stop On the Road From Auschwitz, by Göran Rosenberg, the article discusses how narration representing traumatic memories disturbs narration tied to narrative (normative) memories. Drawing on terms from trauma and memory studies, the article proposes that such novels be read as medical epicrises, each containing a range of symptoms, diagnoses, and specific therapeutic processes. This article specifically examines the so-called identity dissociation of the author/narrator, following the condition's development over the course of the text. Simultaneously, and aided by references to urban studies terminology, the article hypothesizes a process of the reconstruction of a childhood world from a grown-up perspective.
\end{abstract}

Key words: trauma, memory, Shoah, space, identity

Streszczenie: Przedmiotem artykułu jest analiza procesu literackiej (re)konstrukcji naznaczonego traumą dziecięcego świata w autobiograficznej prozie Görana Rosenberga, Krótki przystanek w drodze z Auschwitz. Rzeczony tekst pod wieloma względami autor traktuje jako prozę reprezentatywną dla tzw. drugiego pokolenia po Zagładzie: bezpośrednich potomków Ocalałych, 
funkcjonujących w przestrzeniach tabuizowanych wspomnień i cierpiących na prawach pamięci odziedziczonej. $W$ omawianym utworze autora interesują sposoby, w jakie pamięć traumatyczna symptomatycznie inkrustuje pamięć narracyjną, co w efekcie może prowadzić do (nad)produkcji znaczeń w ramach pozornie normatywnego procesu ewokowania wspomnień. Porusza ponadto problem statusu ontologicznego autora/narratora w aspekcie jego tożsamościowej dysocjacji w płaszczyźnie reminiscencji z okresu dzieciństwa. Propozycja interpretacyjna uwzględnia podjęcie próby jaskrawszej medykalizacji dyskursu literaturoznawczego, tj. potraktowanie prozy (post)pamięciowej jako swoistej medycznej epikryzy: wyodrębnienie treści świadczących o zespole określonych objawów, rozpoznaniu choroby oraz przebiegu terapii.

Słowa kluczowe: trauma, pamięć, Zagłada, przestrzeń, tożsamość

Krótki przystanek $w$ drodze $z$ Auschwitz, autobiograficzna proza autorstwa Görana Rosenberga, cenionego w Szwecji publicysty żydowskiego pochodzenia, to utwór symptomatyczny dla niefikcjonalnej twórczości (post)memorialnej, wpisujący się w kontekst doświadczeń wspólnych dla tzw. drugiego pokolenia po Zagładzie, generacji dojrzewającej w rodzinach Ocalałych z Szoa. Jednocześnie jest on jednym z przynajmniej kilku głośnych tytułów traktujących o wspomnianej tematyce, który pojawił się na szwedzkim rynku wydawniczym w ciągu ostatnich kilku lat (by przywołać tylko 1947. Świat zaczyna się teraz Elisabeth Åsbrink, Dom z dwiema wieżami Macieja Zaremby Bielawskiego, ale też przykład prozy fikcjonalnej, traktującej o romskim doświadczeniu Porajmosu Ja nie jestem Miriam Majgull Axelsson).

W tym miejscu jestem winien czytelnikom wyjaśnienie. Swoje rozważania opieram w całości na polskim tłumaczeniu Krótkiego przystanku..., co u potencjalnego odbiorcy może wprowadzać poczucie metodologicznego dyskomfortu. Wszak, podążając za kanonicznymi tezami Phillipe'a Lejeune'a, dotyczącymi paktu autobiograficznego ${ }^{1}$, przekład stanowi (i to niebagatelne) zapośredniczenie aktu wypowiedzi. W przypadku intymistyki fakt ten wydaje się tym bardziej znaczący i rygorystyczny. Pozwoliłem sobie jednak ową zasadę naruszyć, wprowadzając w relację autor - odbiorca osobę tłumacza, $\mathrm{w}$ nadziei, że nie zaburzy to rozpoznań poczynionych $\mathrm{w}$ toku interpretacji.

${ }^{1}$ Ph. Lejeune: Pakt autobiograficzny. Tłum. A.W. Labuda. „Teksty: teoria literatury, krytyka, interpretacja" 1975, nr 5, s. 39-49. 
Autor, potomek polskich Żydów, dorasta w niewielkim domu, w szwedzkim miasteczku Södertälje Södra, nieopodal Sztokholmu, w pierwszej połowie lat 50. Rozwój osobowości chłopca jest poniekąd determinowany przez dojrzewanie $\mathrm{w}$ przestrzeniach silnie tabuizowanej pamięci rodzinnej, pamięci o wydarzeniach uchylających się normatywnym porządkom artykulacyjnym, wspomnień podlegających restrykcyjnemu wydzielaniu na prawach samorzutnie pojawiających się symptomów pamięci traumatycznej. W efekcie Göran podświadomie nasiąka rodzicielską, niewypowiedzianą traumą. Stanowi ona modelowy przykład fenomenu, opisanego we wczesnych latach 90. XX wieku przez Marianne Hirsch pod nazwą postpamięć. Pozwolę sobie na krótką rekapitulację tego kanonicznego już pojęcia:

Postpamięć charakteryzuje doświadczenie tych, którzy dorastali $\mathrm{w}$ środowisku zdominowanym przez narracje wywodzące się sprzed ich narodzin. Ich własne, spóźnione historie ulegają zniesieniu przez historie poprzedniego pokolenia ukształtowane przez doświadczenia traumatyczne, których nie sposób ani zrozumieć, ani przetworzyć ${ }^{2}$.

Teoria pamięci traumatycznej sięga przełomu XIX i XX wieku, stanowiącego jednocześnie przełom na gruncie badań psychiatrycznych. Pojęcie pamięci traumatycznej do słownika neurologii wprowadził jeden z najbardziej znanych klinicystów francuskich tamtej epoki, doktor paryskiego zakładu Salpêtrière - Pierre Janet ${ }^{3}$. W rezultacie swoich badań rozpoznał dwa rodzaje pamięci: narracyjną oraz traumatyczną. Pierwsza, tzw. zwykła pamięć, „winna być pewnym aspektem życia, zintegrowanym z innymi doświadczeniami" ${ }^{\prime 4}$. Pamięć traumatyczna tymczasem nie wykazuje „charakteru adaptacyjnego" ${ }^{\prime \prime}$, a zatem opiera się procesowi scalenia $\mathrm{z}$ nowymi przeżyciami, nawarstwiającymi się nieustannie $\mathrm{w}$ toku egzystencji każdego człowieka. To same początki, można rzec: praźródła dzisiejszej wiedzy i metodologii badań nad traumą. Posługując się w tekście terminem pamięci traumatycznej, mam już na myśli jej współczesną

${ }^{2}$ M. Hirsch: Żałoba i postpamięć. Tłum. K. Bojarska. W: Teoria wiedzy o przeszłości na tle współczesnej humanistyki. Antologia. Red. E. Domańska. Poznań 2010, s. 254.

${ }^{3}$ B.A. van Der KolK, O. van der Hart: Natrętna przeszłość: elastyczność pamięci $i$ piętno traumy. Tłum. T. Bilczewski i A. Kowalcze-Pawlik. W: Antologia studiów nad traumą. Red. T. Łysak. Przekł. T. Bilczewski, K. Bojarska, J. Burzyński, A. Kowalcze-Pawlik, A. Rejniak-Majewska. Kraków 2015, s. 139.

${ }^{4}$ Ibidem, s. 146.

${ }^{5}$ Ibidem. 
definicję autorstwa wybitnej badaczki nurtu memorialnego - Cathy Caruth. Ten rodzaj pamięci $w$ jej rozważaniach występuje na prawach mechanizmu mimowolnego pojawiania się wspomnień pod wpływem określonego (niekoniecznie gwałtownego) impulsu, gdzie „błahe wydarzenia mają [...] moc przywoływania symptomów traumatycznych, podobnie jak [Proustowska - M.F.] magdalenka przypominała doświadczenia sensualne" ${ }^{\prime \prime}$.

W oczach małego Rosenberga symptomy pamięci traumatycznej, zgodnie z ich naturą, pozostają całkowicie nierozpoznane, przy czym często towarzyszy im osobliwa atmosfera, którą autor określa mianem cieni: „Zdarza się parę razy, że jego świat odtrąca go z powrotem ku ich [rodziców - M.F.] światu i ich cienie na moment wdzierają się w niego, pozostawiając doznanie mroku i chłodu"7.

Dopiero po kilkudziesięciu latach dojrzały Göran podejmie próbę rozpoznania istoty owych "cieni" - i na podstawie zapośredniczonych materiałów dokona rekonstrukcji pamięci rodzinnej sprzed czasu własnego przyjścia na świat. Nim to nastąpi, pisarz zrestauruje również świat swojego dzieciństwa. Tym samym formę Krótkiego przystanku... wpisać można w stricte medyczny gatunek wypowiedzi, jakim jest lekarska epikryza: sporządzony post factum opis przypadku z wyróżnioną gamą objawów, rozpoznaniem i zaordynowaniem terapii. Jednocześnie $\mathrm{w}$ strukturze tekstu, $\mathrm{w}$ ramach poszczególnych wypowiedzi, wyraźne ujawniają się poszczególne „sploty wiedzy i niewiedzy"8 o wydarzeniu traumatycznym. Innymi słowy: Nachträglichkeit (jeszcze Freudowska obserwacja, wedle której „przeszłość staje się dostępna jedynie za sprawą opóźnionego aktu rozumienia i interpretacji"9) wprowadza niezanikający ani na chwilę dysonans, wyznaczający narracyjną oś tekstu. Dysocjacja figury autora/narratora, która temu procesowi towarzyszy, zostanie przeze mnie omówiona w dalszych partiach artykułu.

Zanim przejdę do właściwej interpretacji, chciałbym jeszcze przywołać fragment tekstu Katarzyny Bojarskiej, odnoszący się do twórczości Winfrieda Sebalda, który, moim zdaniem, świetnie cechuje, w zasadzie definiuje, zarówno prozę (post)memorialną, jak i egzystencjalne położenie Görana Rosenberga - nie tylko z okresu

${ }^{6}$ T. Łysak: Trauma - od genealogii pojęcia do studiów nad traumą. W: Antologia studiów nad traumą..., s. 13.

${ }^{7}$ G. Rosenberg: Krótki przystanek w drodze z Auschwitz. Tłum. M. KalinowsKi. Wołowiec 2014, s. 41.

8 T. ŁysaK: Trauma - od genealogii pojęcia do studiów nad trauma..., s. 13.

${ }^{9}$ R. Leys: Freud i trauma. Tłum. A. Rejniak-Majewska. W: Antologia studiów nad trauma..., s. 112. 
dzieciństwa, ale również czasu, gdy jako dojrzały publicysta zdecydował się na konfrontację z rodzinną przeszłością:

Wydarzeniem fundującym pisarstwo [...] jest katastrofa, która miała miejsce, gdy go jeszcze nie było: Zagłada europejskich Żydów. Pisarz stał się spadkobiercą nieodkupionego cierpienia i odtąd chce zrozumieć bycie człowiekiem w czasie, którego zasadniczym elementem jest czas historyczny. W tym ujęciu wszelka historia po katastrofie jest traumatyczna; nie było nas, kiedy zachodziło wydarzenie historyczne o takiej sile rażenia, która determinuje naszą egzystencję w świecie „po". Nie można ogarnąć ani włączyć $\mathrm{w}$ swoje życie tego katastroficznego wydarzenia, powraca ono z opóźnieniem i kładzie się cieniem na wszystkim innym ${ }^{10}$.

(Post)memorialna narracja Krótkiego przystanku... jest zatem próbą rekonstrukcji świata na zgliszczach, stanowiących fragmentaryczną, ale jednak - opokę. Zarazem próba ta dokonuje się wobec całkowitej pustki - wyrwy, w jakiej funkcjonują rodzice pisarza. Jak o nich pisze Göran Rosenberg:

W świecie tych dwojga nowo przybyłych [do Szwecji - M.F.] już nie ma miejsca takiego jak to. Miejsca, gdzie oni, w ten sam sposób jak kiedyś ja, uczynili świat swoim. Gdyby istniało takie miejsce, mówiliby o nim, dając mi poznać jego zapach, jego smak, zabraliby mnie tam, opowiadaliby o ludziach, którzy kiedyś tam żyli. Ale oni nie opowiadają. Tam, gdzie kiedyś musiało istnieć jakieś miejsce, takie jak to, teraz jest tylko cisza [...]. I choćby jakieś ułomki takiego miejsca jeszcze leżały gdzieś ukryte [...], to ktoś lub coś nazbyt dokładnie je zmiażdżyło, nazbyt głęboko zakopało, $\mathrm{w}$ nazbyt rozległych strefach mroku ${ }^{11}$.

Moment "tuż-przed" rozwinięciem pierwszego z wątków narracji wydaje się w ramach rzeczonej prozy najbardziej intrygujący.

\section{Topograficzne wyznaczniki rekonstruowanego świata}

Historię rozpoczyna opis przerzuconego nad Kanałem Mostu, prowadzącego do Miejsca narodzin autora. Figura Mostu, niezależnie od "normatywnego" wzoru metaforyzacji, kiedy to przyjmuje

${ }^{10}$ K. Bojarska: Sztuka niemożliwej możliwości. „Teksty Drugie” 2010, nr 5, s. 164.

${ }^{11}$ G. Rosenberg: Krótki przystanek..., s. 46. 
on status klucza lub pasażu, stanowi - jak się wydaje - czynnik inicjujący wspomnienia $\mathrm{z}$ okresu dzieciństwa. Zapowiada tym samym wybór strategii narracyjnej, na mocy której wiodącą metodą prowadzącą do (re)konstrukcji dziecięcego świata stanie się wpisywanie pamięciowej materii $\mathrm{w}$ matrycę topo(bio)graficzną. Most, Kanał i Miejsce konsekwentnie pisanie są wielką literą, co wskazuje na ich konstytutywny charakter $w$ stosunku do odtwarzanej ze wspomnień przestrzeni; określoną funkcję delimitacyjną. Świat małego Rosenberga nie wykracza ani poza Miejsce, ani przerzucony nad Kanałem Most.

Proces wskrzeszania świata nie zachodzi oczywiście wyłącznie $\mathrm{w}$ ramach pamięci autora/narratora, stanowiąc raczej amalgamat obrazów wywodzących się z poszczególnych porządków memorialnych. Przede wszystkim to pamięć autobiograficzna ${ }^{12}$ - zdefiniowana przez francuskiego socjologa Maurice'a Halbwachsa, jako indywidualna pamięć każdego człowieka. W dalszej kolejności pozwalam sobie wyodrębnić kategorię pamięci potencjalnie protetycznej, do której przyporządkowuję formuły zdradzające autorską niepewność w kwestii autentyczności własnych wspomnień. Zwracam wreszcie uwagę na poszczególne porządki pamięci kolektywnejis: kategorie z domeny rozważań nestorów zwrotu memorialnego, Aleidy i Jana Assmannów. Składają się na nią treści w różnym stopniu wykorzystujące mechanizm interpersonalnych, społecznych zapośredniczeń. Jest to oczywiście pamięć komunikacyjna, przekazywana w partykularnych społecznościach, np. rodzinnych, pokoleniowych - w formie ustnej (występowanie postpamięci musi jednak świadczyć o niemożności zaistnienia takiej formy przekazu w ramach rodzinnego kręgu Rosenbergów). Dalej: to pamięć zdeponowana w archiwach państwowych (muzeach, ośrodkach kultury o długiej tradycji, bibliotekach etc.). Do charakterystycznych dla omawianej prozy kategorii z zakresu pamięci kolektywnej należy odkrywana i rekonstruowana przez narratora pamięć getta (kronika Litzmannstadt, dzienniki osobiste, obwieszczenia żydowskiej administracji, niemiecka dokumentacja zbrodni). To właśnie z nich korzysta autor, konstruując świat swoich rodziców. W ramach omawianej prozy wyróżniam wreszcie paradoksalną (nie)pamięć świata sprzed Zagłady, a zatem ten rodzaj narracji, w ramach której ujawnia się niewyrażalność Holokaustu;

12 J.K. Olıск, J. RobBıns: Badania nad pamięcia społeczna: od "pamięci zbiorowej" do socjologii historycznej praktyk pamięciowych. Tłum. Lidex. W: (Kon)teksty pamięci. Antologia. Red. K. Kończal. Warszawa 2014, s. 108.

13 Ibidem, s. 109. 
sceny niedające się wypełnić nawet za pomocą zapośredniczonych świadectw, sytuacje „wyrwane" z pamięci:

Próbuję wyobrazić sobie samotność w wagonach. Samotność w momencie, kiedy rygluje się za wami drzwi wagonu i świat taki, jakim niedawno jeszcze wam się zdawał, opuszcza was nieodwołalnie ${ }^{14}$.

Wszystkie wymienione memorialne domeny są wobec siebie komplementarne, wytwarzając w obrębie narracji polifonię rejestrów. Wobec tak sylwicznego, wirydarzowego charakteru prozy, czasoprzestrzeń w Krótkim przystanku... jawi się w postaci zatrzymanych w kadrze fotografii czy też (podążając za słowami autora) "ułomków” bądź „refleksów pamięci” - wyświetlanych jak gdyby w epidiaskopie, w czasie gramatycznie teraźniejszym, na prawach onirycznej, palimpsestowej projekcji. Warto notabene zwrócić uwagę na samą, przyjętą przez autora formułę „ułomka pamięci”: czegoś niepełnego, zdeformowanego, ale też sprawiającego ból, przynoszącego cierpienie. $\mathrm{W}$ planie narracyjnym proces ewokowania wspomnień przypomina symptomatyczne, autogenne generowanie fragmentarycznych krajobrazów, stanowiących tło - jakby sztafaż określonego wspomnienia. $\mathrm{W}$ ten sposób następuje sukcesywne wypełnianie literackiej czasoprzestrzeni poszczególnymi (kraj)obrazami. Pamięć narratora zatacza coraz szersze kręgi, odpowiadające dojrzewaniu małego Görana - tak, aby ich granice sygnalizowały dalsze etapy dziecięcej inicjacji:

Pierwszym ptakiem jest wróbel w krzaku berberysu pod sklepem nabiałowym. Pierwsza wiewiórka wdrapuje się po pierwszej korze na pierwszą sosnę pod kuchennym oknem [...]. Pierwsza leśna ścieżka usłana jest pierwszym nagrzanym świerkowym igliwiem i otoczona pierwszymi jagodami... ${ }^{15}$.

Następujące po sobie perspektywy definiowane są przez wąski pas zieleni przed domem, jarzębinową alejkę, Morskie Kąpielisko czy nasyp kolejowy. Rzutowane w przestrzeń literacką klisze pamięci jawią się jako wyblakłe, pocięte, nadtopione, na różny sposób zniekształcone upływem czasu. Okazują się zdeformowane jednak nie tylko na mocy naturalnych procesów przypominania

${ }^{14}$ G. Rosenberg: Krótki przystanek..., s. 95.

${ }^{15}$ Ibidem, s. 24. 
i „odpominania"16. Na dużą część z nich padają wspomniane na początku traumatyczne "cienie", będące W istocie symptomami dokonanego w dzieciństwie procesu inkorporacji ojcowskiej traumy. Jej obecność ujawnia się pod postacią zdarzeń etiologicznie odmiennych wobec naturalnych przekształceń pamięci narracyjnej. Należą do nich niespodziewane intruzje, gwałtowne pęknięcia wątku czy też jego "wykolejenie", „cichnięcie" rejestru i freudowskie pomyłki. Nadto na istnienie traumatycznego dysonansu wewnątrz pozornie normatywnego wzorca wspomnień wskazuje niestabilne ontologicznie narracyjne ,ja".

\section{Tożsamościowa dysocjacja jako wyznacznik literatury (post)memorialnej}

Zabieg tożsamościowej dysocjacji, pozornie zrywający z zasadą jedności autora i narratora, a zatem naruszający Lejeune'owski pakt autobiograficzny, należy do często obieranych strategii narracyjnych w postmemorialnej literaturze faktu. Strategia opisywania siebie jako „nie-siebie" lub „nie-do-końca-siebie” pozwala osiągnąć analityczny dystans, niezbędny, aby przebrnąć przez doświadczenia związane z niezrozumiałym samobójstwem ojca, nadać znaczenie niewłączonym dotychczas w obręb języka doznaniom z dzieciństwa i wreszcie uporządkować treści, do tej pory ujawniające się w autogennych kadrach pamięci. Innymi słowy: dysocjacja służy „przepracowaniu” doświadczenia traumatycznego. $W$ tym sensie pozostaje symptomem i środkiem leczniczym jednocześnie.

Nieco odmienne znaczenie terminowi „dysocjacja” przypisują holenderscy psychiatrzy - Bessel A. van der Kolk i Onno van der Hart. Zjawisko to odnoszą nie do tożsamości osoby straumatyzowanej, a samego traumatycznego doświadczenia:

Współczesne badania wykazują, że do dysocjacji traumatycznego doświadczenia dochodzi w momencie pojawienia się traumy [...]. Wiele osób, które przeżyły traumę, uparcie utrzymuje, że podlegają automatycznemu usunięciu ze sceny traumatycznych wydarzeń; spoglądają na nią z dystansu lub zupełnie z niej znikają, innym częściom swej osobowości pozostawiają cierpienie i przechowywanie przytłaczających doświadczeń17

${ }^{16}$ P. Czapliński, K. Kończal: Odpominanie. W: Modi memorandi. Leksykon kultury pamięci. Red. M. Saryusz-Wolska, R. Traba. Warszawa 2014, s. 301-303.

17 B.A. van der Kolk, O. van der Hart: Natrętna przeszłość..., s. 155. 
Należy podkreślić, iż, według wspomnianych specjalistów, dysocjacja sama $\mathrm{w}$ sobie nie służy przepracowaniu traumy właśnie ze względu na istotę dysocjacyjnego „rozszczepienia”, towarzyszącego nawrotom traumatycznych obrazów. Cykliczne nawroty scen będących źródłem traumy, obserwowane "spoza siebie” pozostają po prostu nieleczonymi symptomami.

Osobiście proponuję nieco inne zastosowanie terminu „dysocjacja", odnoszę (jak już podkreśliłem), wiążąc go z figurą autora; stąd określam ją mianem dysocjacji tożsamościowej narratora. Stabilizacja narracyjnego ,ja" wraz z postępem historii wskazywałaby w tym przypadku na zakończenie sukcesem procesu „przepracowywania” traumy. Analogie pomiędzy wypowiedziami holenderskich psychiatrów a moją propozycją są jednak możliwe do przeprowadzenia. Badacze piszą o usunięciu ofiary ze sceny traumatycznych wydarzeń we własnych wspomnieniach. W Krótkim przystanku... dysocjacja tożsamościowa nie wydaje się tak dramatyczna. W pierwszej kolejności sygnalizowana jest tekstowym sposobem zapisu wyrazu Dziecko. Wielka litera rozpoczynająca wyraz wpisuje się w ciąg słów kluczy, obok Miejsca czy Projektu: „Nic nie może oddzielać Dziecka od Miejsca. Żadne obce słowa, żadne obce imiona. Nic, co mogłoby pozbawić punktu oparcia dla nich wszystkich"18. W innym fragmencie autor pisze z kolei o „matce dziecka, które z czasem stanie się mną"19.

W ramach obranej strategii narracyjnej, Dziecko wydaje się określonym konstruktem, elementem Projektu, który w teorii powinien zapewnić spokojne życie ocalałym z Szoa Rosenbergom w nowym kraju. W poszczególnych scenach ujawnia się stosunek narratora do postaci ojca i matki: „Woła mnie tamta młoda kobieta, która teraz jest moją matką, i woła w pierwszym języku, którego się nauczyłem, i pierwszym, którego zapomnę"20. I jeszcze jeden przykład: „No cóż, ja sam o tym jeszcze nic nie wiem, bo jeszcze nie znam tego człowieka, który właśnie wysiadł z pociągu i który jeszcze nie jest moim ojcem..." ${ }^{\prime 2}$. Obecny we fragmentach odnoszących się do obojga rodzicieli, a wynikający $\mathrm{z}$ dystansu osiągniętego $\mathrm{w}$ procesie dysocjacji, swoisty "chłód emocjonalny" sprawia, iż relacje rodzinne nie są w stanie wybrzmieć na prawach "normatywnej” narracji wspomnieniowej. Ciężar zapośredniczonej traumy, symptomatycznie inkrustującej na wpół oniryczną opowieść, automatycznie unieważnia

\footnotetext{
18 G. Rosenberg: Krótki przystanek..., s. 23.

19 Ibidem, s. 218.

${ }^{20}$ Ibidem, s. 23.

${ }^{21}$ Ibidem, s. 10.
} 
bowiem wszystkie te miejsca, w których autor dąży do zachowania normatywnego charakteru „wspomnień z dzieciństwa” ${ }^{22}$. Wdzierające się $\mathrm{w}$ pamięć narracyjną symptomy powodują punktowe „wyciszenie" pozornie radosnych wątków, jednocześnie podskórnie sygnalizując faktyczny brak przynależności rodziców do świata Dziecka, a tym samym antycypując nieuchronną porażkę Projektu. Opowieść rozpięta między kroniką a gawędą nieustannie podsyła tropy świadczące o dysonansie poznawczym: mimowolnie dającej o sobie znać odrębności wobec współmieszkańców miasteczka nieprzystawalności wynikającej ze skrajnej specyfiki doświadczeń i pojawiających się na ich bazie skojarzeń: „Specjalnością piekarni jest słodkie pieczywo nazywane chałką ss od piekarni ss, która swą nazwę bierze od lokalizacji, to znaczy Södertäjle Södra, ale my tej bułki nie kupujemy" ${ }^{23}$. Tropy te niczym intruzje rozdzierają „normatywną" narrację „o sobie i miejscu”. W innych scenach przybierają formy klasycznych freudowskich pomyłek, jak np. we fragmencie: „To właśnie jest Miejsce. To tu mój świat nabiera swoich pierwszych barw, blasków, zapachów, dźwięków, gestów, imion, słów"24. Nieco dalej: „To jest Miejsce, którego piętno [podkr. - M.F.] zawsze będę nosić w sobie..."25.

To zatem Miejsce odcisnęło w pamięci Görana Rosenberga "piętno", nie: „piękno", jak można by suponować po poprzedzającym opisie "szczenięcych lat" i definiowaniu rzeczonego Miejsca w kategoriach przynależności, adaptacji, uczynienia „swoim”, „własnym”. Również pochodzenie autora, a raczej związane z nim piętno antysemityzmu, dociera do chłopca w pierwszej kolejności za pośrednictwem symptomów. Oczywiście, Göran we właściwym dla niego czasie, na swój dziecięcy sposób pojmuje, że podobnie jak rodzice, on również jest Żydem. Niedopuszczenie autora-dziecka do historii rodzinnej z okresu sprzed osiedlenia się w Szwecji sprawia, że zetknięcie z pierwszymi, pośrednimi przejawami wrogości stanowi dlań szczególnie dotkliwy wstrząs. Jednocześnie to właśnie przemoc o jednoznacznie antysemickim charakterze, z jaką spotykają się Rosenbergowie w "nowym” kraju, przesądza o tym, iż (auto)ordynowany przez rodziców Görana zabieg amnestycznego odcięcia od

${ }^{22}$ Warto zaznaczyć, iż impulsy odnoszące się do czasu Zagłady ujawniają się w narracji prowadzonej zarówno z perspektywy dojrzałego pisarza, jak i Dziecka.

${ }^{23}$ G. Rosenberg: Krótki przystanek..., s. 26.

${ }^{24}$ Ibidem, s. 17.

${ }^{25}$ Ibidem. 
przeszłości okazuje się niemożliwy do przeprowadzenia. Zwłaszcza ojciec, Dawid, po pewnym czasie zaczyna odczuwać „fantomowe bóle" po utraconym świecie.

Warto w tym kontekście przywołać szczególnie symptomatyczną scenę, w której rówieśnicy Görana, wołając: „Żydzi!” - ciskają śnieżnymi kulkami w kuchenną szybę Rosenbergów. Göran spogląda na matkę, a ta z niezrozumiałych dla niego przyczyn „robi się biała na twarzy. Całkiem bieleje i cichnie. Nic nie mówi" ${ }^{26}$. Chłopiec jest już starszy, zatem i wspomnienia układają się bardziej na wzór konkretnych scen aniżeli efemerycznych refleksów. Zakaz mówienia o przeszłości sprawia jednak, że zupełnie nie potrafi odczytać reakcji swojej rodzicielki. Nieprzekładalność traumy Zagłady na język oraz towarzysząca relacji rodzic - dziecko niechęć do poruszania jakichkolwiek tematów związanych z przemocą wobec Żydów odpowiadają za porażkę systemu, który w teorii powinien chronić Görana. Właśnie z tego powodu wszelkie podejmowane działania maskujące (przede wszystkim próba unifikacji z nowym społeczeństwem) nie zagwarantują powodzenia Projektu; nie sprawią, że Göran będzie dorastać w przeciętnej szwedzkiej rodzinie, w schludnym szwedzkim miasteczku przy jarzębinowej alei. Nie zabezpieczą malca przed konfrontacjami z pierwszymi przejawami antysemityzmu w życiu, stanowiącymi jak gdyby rewers normatywnych porządków inicjacyjnych. Zabieg mimikry okaże się zabójczy dla ojca autora.

Gdy Göran przytacza treść listu swojego ojca do matki z czasu przyjazdu Dawida do Szwecji, w płaszczyźnie narracyjnej dochodzi do kolejnej freudowskiej pomyłki: niespodziewanej intruzji symptomatycznego, semantycznego „wykolejenia”. Referując treść korespondencji, narrator w pewnym momencie wspomina o dwojgu „młodych, którzy rozstali się na rampie selekcyjnej w Auschwitz-Birkenau. Nie, którzy ostatnio rozstali się na peronie w Alingsås"27.

Zaraz później dodaje usprawiedliwiająco: „Już nie tak łatwo odróżnić jedno pożegnanie od drugiego" ${ }^{28}$. Powstaje wrażenie, jakby ostatnie zdanie nie pochodziło od narratora. Zostało wypowiedziane nie tyle „w imieniu”, ile „za" ojca. Syn mimowolnie przyjmuje perspektywę rodziciela, stając się jego pośmiertnym brzuchomówcą. Sytuacja powtarza się w dalszych partiach tekstu, gdy autor inicjuje „,rozmowę" z Dawidem. Niemożliwe do wyartykułowania odpowie-

${ }^{26}$ Ibidem, s. 41.

${ }^{27}$ Ibidem, s. 14 .

${ }^{28}$ Ibidem. 
dzi wypełniają wyobrażenia i supozycje, oparte na lekturach zapośredniczonych świadectw, akt czy obwieszczeń z czasu Zagłady, ale także prywatnej korespondencji Rosenbergów. Jest to zatem artykulacja podwójnie zastępcza, lecz w istniejącej sytuacji jedyna możliwa do zaistnienia.

Wydaje się, że do zjednoczenia narracyjnego „ja” autor/narrator zbliża się we fragmentach stanowiących rekonstrukcję ostatnich miesięcy życia Dawida Rosenberga: najpierw przywołując treść faktycznych lekarskich epikryz ze szpitala psychiatrycznego, a następnie dopuszczając w płaszczyznę narracji rejestr traumatyczny, ujawniający się $\mathrm{w}$ krótkich, rwanych zdaniach, rozpoczynanych od następnych wersów; zdaniach, które - jak sądzę - najwyraźniej oddają właśnie charakter „ułomków pamięci”. Taką poetykę przybiera artykułowanie traumy pomimo czy też na przekór otwierającemu wypowiedź zapewnieniu ze strony autora: „Ostatnie lato [czas samobójczej śmierci ojca - M.F.] pamiętam bardzo dobrze"29. Co znamienne: obok wyliczanych we wspomnieniu osób nie pojawia się autor, co świadczy o „usunięciu ze sceny traumatycznych wydarzeń" podmiotu wspominającego, o czym piszą holenderscy psychiatrzy, przywołani na początku artykułu. Wydaje się zatem, iż proces tożsamościowego jednoczenia może (ale nie musi) być tylko wstępem do uwolnienia się od traumy już niezapośredniczonej, ale tej własnej, dotyczącej samobójczej śmierci ojca. Pozwalam sobie przytoczyć rzeczony fragment w całości:

Powietrze drżące w popołudniowym skwarze nad żwirową drogą prowadzącą w górę, do zabudowań gospodarczych i na parking przy bramie wjazdowej.

Małą procesję odrywająca się od paska zieleni.

Jak nieskończenie wolno się posuwa.

Jakby chciała wydłużyć nie tylko kroki, ale i czas.

Rozciągnąc czas między przed i po.

Trzy osoby kroczące powoli przez ostatnie lato.

Mama, Natek, Kerstin.

Rozumiem już, nim czas się skończył ${ }^{30}$.

Odnoszę w końcu wrażenie, że skuteczność autoterapii dotyczącej traumy zapośredniczonej wybrzmiewa w finalizującej opowieść trzywersowej kodzie, w której autor w kategoryczny, otwarty sposób dokonuje afirmacji swojej tożsamości przy jednoczesnym zaakcep-

${ }^{29}$ Ibidem, s. 313.

${ }^{30}$ Ibidem. 
towaniu ostatecznego losu ojca. Ramą modalną tej kody staje się na powrót Miejsce, centrum Rosenbergowego mikrowszechświata:

Dla mnie - miejsce, gdzie wszystkie horyzonty są otwarte. Dla ciebie - miejsce, gdzie wszystkie horyzonty są zamknięte. Dla ciebie - krótki przystanek w drodze z Auschwitz ${ }^{31}$.

\section{Bibliografia}

Bojarska K.: Sztuka niemożliwej możliwości. „Teksty Drugie” 2010, nr 5, s. 156-166.

Czapliński P., Kończal K.: Odpominanie. W: Modi memorandi. Leksykon kultury pamięci. Red. M. Saryusz-Wolska, R. Traba. Warszawa 2014, s. 301-303.

Hirsch M.: Żałoba i postpamięć. Tłum. K. Bojarska. W: Teoria wiedzy o przeszłości na tle wspótczesnej humanistyki. Antologia. Red. E. Domańska. Poznań 2010, s. 247-280.

Kolk B.A. van der, Hart O. van der: Natrętna przeszłość: elastyczność pamięci i piętno traumy. Tłum. T. Bilczewski i A. Kowalcze-Pawlik. W: Antologia studiów nad trauma. Red. T. Łysak. Przeł. T. Bilczewski, K. Bojarska, J. Burzyński, A. Kowalcze-Pawlik, A. Rejniak-Majewska. Kraków 2015, s. 139-174.

Lejeune Ph.: Pakt autobiograficzny. Tłum. A.W. Labuda. „Teksty: teoria literatury, krytyka, interpretacja" 1975, nr 5, s. 31-49.

Leys R.: Freud i trauma. Tłum. A. Rejniak-Majewska. W: Antologia studiów nad trauma. Red. T. Łysak. Przeł. T. Bilczewski, K. Bojarska, J. Burzyński, A. Kowalcze-Pawlik, A. Rejniak-Majewska. Kraków 2015, s. 109-137.

Łysak T.: Trauma - od genealogii pojęcia do studiów nad trauma. W: Antologia studiów nad trauma. Red. T. Łysak. Przeł. T. Bilczewski, K. Bojarska, J. Burzyński, A. Kowalcze-Pawlik, A. Rejniak-Majewska. Kraków 2015, s. 5-30.

Olıск J.K., RobBins J.: Badania nad pamięcia społeczna: od,pamięci zbiorowej" do socjologii historycznej praktyk pamięciowych. Tłum. Lidex. W: (Kon)teksty pamięci. Antologia. Red. K. Kończal. Warszawa 2014, s. 99-140.

Rosenberg G.: Krótki przystanek w drodze z Auschwitz. Tłum. M. Kalinowski. Wołowiec 2014.

Mateusz Florczak - krytyk artystyczno-literacki, doktorant Instytutu Filologii Polskiej na Wydziale Filologicznym Uniwersytetu Gdańskiego. Jego zainteresowania akademickie ogniskują się w horyzoncie badań nad Zagładą, studiów nad traumą i pamięcią oraz zwrotu przestrzennego. Za przedmiot teoretycznoliterackich analiz obiera szeroko rozumianą literaturę faktu (dzienniki, reportaże, memuary, relacje, prozę autobiograficzną etc.).

e-mail: mateuszflorczak.filo@icloud.com

31 Ibidem, s. 314. 
